\title{
NKCC1 Phosphorylation Stimulates Neurite Growth of Injured Adult Sensory Neurons
}

\author{
Simon Pieraut, ${ }^{1,2}$ Valérie Laurent-Matha, ${ }^{1,2}$ Chamroeun Sar, ${ }^{1}$ Thomas Hubert, ${ }^{1}$ Ilana Méchaly, ${ }^{1,2}$ Cécile Hilaire, ${ }^{3}$ \\ Marcel Mersel, ${ }^{1}$ Eric Delpire, ${ }^{4}$ Jean Valmier, ${ }^{1,2}$ and Frédérique Scamps ${ }^{1}$ \\ ${ }^{1}$ Inserm, Unité 583, F-34000 Montpellier, France, ${ }^{2}$ Université Montpellier II, F-34000 Montpellier, France, ${ }^{3}$ Université Franche Comté, F-25000 Besançon, \\ France, and ${ }^{4}$ Vanderbilt University, Nashville, Tennessee 37235
}

\begin{abstract}
Peripheral nerve section promotes regenerative, elongated neuritic growth of adult sensory neurons. Although the role of chloride homeostasis, through the regulation of ionotropic GABA receptors, in the growth status of immature neurons in the CNS begins to emerge, nothing is known of its role in the regenerative growth of injured adult neurons. To analyze the intracellular $\mathrm{Cl}^{-}$variation after a sciatic nerve section in vivo, gramicidin perforated-patch recordings were used to study muscimol-induced currents in mice dorsal root ganglion neurons isolated from control and axotomized neurons. We show that the reversal potential of muscimol-induced current, $E_{\mathrm{GABA}-\mathrm{A}}$, was shifted toward depolarized potentials in axotomized neurons. This was attributable to $\mathrm{Cl}^{-}$influx because removal of extracellular $\mathrm{Cl}^{-}$prevented this shift. Application of bumetanide, an inhibitor of NKCC1 cotransporter and $E_{\mathrm{GABA}-\mathrm{A}}$ recordings in sensory neurons from $\mathrm{NKCC1}^{-/-}$mice, identified NKCC1 as being responsible for the increase in intracellular $\mathrm{Cl}^{-}$in axotomized neurons. In addition, we demonstrate with a phospho-NKCC1 antibody that nerve injury induces an increase in the phosphorylated form of NKCC1 in dorsal root ganglia that could account for intracellular $\mathrm{Cl}^{-}$accumulation. Time-lapse recordings of the neuritic growth of axotomized neurons show a faster growth velocity compared with control. Bumetanide, the intrathecal injection of NKCC1 small interfering RNA, and the use of $\mathrm{NKCC1}^{-1-}$ mice demonstrated that NKCC1 is involved in determining the velocity of elongated growth of axotomized neurons. Our results clearly show that NKCC1-induced increase in intracellular chloride concentration is a major event accompanying peripheral nerve regeneration.
\end{abstract}

Key words: NKCC1; phosphorylation; regenerative growth; injury; chloride homeostasis; DRG

\section{Introduction}

Axotomy of adult peripheral neurons induces rapid axon regeneration. This has been demonstrated in vivo (Tanaka et al., 1992; Jacob and McQuarrie, 1993) and in vitro (Smith and Skene, 1997; Lankford et al., 1998; Andre et al., 2003) in which a conditioning lesion increases the ability of the associated primary afferent neuron to regenerate successfully. Molecular mechanisms responsible for this increased neuronal growth ability are accompanied by a shift in cellular organization, such as the appearance of growth cones at the proximal tip of the lesioned axons and the swelling of the neuronal cell body associated with a strong increase in cellular metabolism and protein synthesis (Makwana and Raivich, 2005). Transcriptomic analysis of gene expression after peripheral nerve injury has led to the identification of many injury-related and regeneration-associated genes, such as regulatory proteins including growth factor receptors and transcription factors (Araki

\footnotetext{
Received March 26, 2007; revised May 4, 2007; accepted May 7, 2007.

This work was supported by the Association Française contre les Myopathies and the Ministère de la Recherche (S.P.) and National Institutes of Health Grant NS36758 (E.D.). We are very grateful to Dr. B. Forbush for the gift of anti-phospho-NKCC1 antibody R5; to Dr. H. Boukhaddaoui and the regional imaging platform, RIO, for image acquisition and analysis; to J. L. Pasquier for artwork; and to Dr. P. Carroll for critical comments on this paper.

Correspondence should be addressed to Dr. Frédérique Scamps, Institut des Neurosciences de MontpellierHôpital St. Eloi, Inserm Unité 583, 80, rue Augustin Fliche, 34091 Montpellier Cedex 5, France. E-mail: scamps@univ-montp2.fr.

DOI:10.1523/JNEUROSCI.1337-07.2007

Copyright $\odot 2007$ Society for Neuroscience $\quad$ 0270-6474/07/276751-09\$15.00/0
}

et al., 2001; Xiao et al., 2002; Mechaly et al., 2006). The role and the mechanisms controlling the intracellular ionic strength accompanying the increase in cell size necessary to neurite growth are less known.

Among the mechanisms controlling the intracellular ionic strength, the regulation of cell volume is a complex process that involves the activity of membrane ion channels and cotransporters (Lang et al., 1998). The ubiquitously expressed protein NKCC1 (encoded by the slc12a2 gene), plays a "housekeeping" role in cell volume regulation. NKCC1 is an electroneutral transporter responsible for the entry of $\mathrm{Na}^{+}, \mathrm{K}^{+}$, and $\mathrm{Cl}^{-}$into the cell and is expressed in dorsal root ganglion (DRG) neurons (Plotkin et al., 1997). Its activity is believed to be primarily responsible for the high intracellular $\mathrm{Cl}^{-}$concentration, $\left[\mathrm{Cl}^{-}\right]_{\mathrm{i}}$, in peripheral nervous system (Sung et al., 2000; Alvarez-Leefmans et al., 2001). Most studies on the functional role of NKCC1 in sensory neurons are related to the control of cellular excitability through chloride channels such as the $\mathrm{GABA}_{\mathrm{A}}$ receptor (Sung et al., 2000; Laird et al., 2004). In agreement with its role in presynaptic inhibition, disruption of NKCC1 in mice leads to altered pain perception (Delpire et al., 1999). However, studies on non-neuronal cells have demonstrated that, in addition to maintaining cell volume during hypo-osmotic or hyperosmotic challenge, volume regulatory mechanisms are also used to initiate changes in cell volume, as required for cell growth and differentiation (O'Neill, 1999). 
Conceptually, besides its role in cell excitability, activation of NKCC1 in the absence of cell shrinkage could lead to cell enlargement. Moreover, the rapid activation of NKCC1 through phosphorylation by growth factors in non-neuronal cells lends credence to a role of NKCC1 in cell growth (Waldegger et al., 1998; Jiang et al., 2001).

The contribution of NKCC1 to the process of neurite growth has to our knowledge never been addressed. To examine this, we analyzed the role and regulation of NKCC1 in the regenerative growth of sensory neurons in vitro conditioned with a peripheral nerve injury in vivo.

\section{Materials and Methods \\ Animals and surgery}

Adult Swiss mice (CERJ, Le Genest St. Isle, France) and C57BL/6 mice (6-8 weeks of age) were housed in cages with a $12 \mathrm{~h}$ light/dark cycle and fed food and water ad libitum. The care and use of mice conformed to institutional policies and guidelines. Mice were deeply anesthetized by isoflurane inhalation. The left sciatic nerve was exposed at the midthigh level and sectioned, and a 3-5 mm fragment of nerve was removed. Mice were kept alive for 4-10 d and then were killed by $\mathrm{CO}_{2}$ inhalation, followed by cervical dislocation, and their lumbar DRG L4-L5 were removed.

\section{Gene knockdown experiments}

Small interfering RNAs. Pooled nontargeting control small interfering (siRNA) or specific siRNA against NKCC1 $(s l c 12 a 2)$ used in this study were the on-target plus SMART pools from Dharmacon [Perbio Science, Brebières, France; Dharmacon catalog \#L-044448-01 targeting NKCC1 (GenBank accession number NM_009194)].

Preparation of the RNA-polymer complex. The method used for intrathecal delivery was adapted from one reported previously (Tan et al., 2005). For polyethylenimine (PEI) complexation, $5 \mu \mathrm{g}$ of specific or nonspecific siRNAs were complexed with $1.8 \mu \mathrm{l}$ of $200 \mu \mathrm{M}$ linear lowmolecular-weight PEI ExGen 500 (Euromedex, Souffelweyersheim, France). RNA-polymer complexes were allowed $10 \mathrm{~min}$ to form at room temperature. To allow visualization of transfected cells, $3 \mathrm{~mm}$ dextrantetramethylrhodamine (Invitrogen, Cergy Pontoise, France) were added to the $5 \%$ glucose solution containing the RNA-polymer complex.

In vivo delivery of siRNA. Six to $8 \mu \mathrm{l}$ of the final solution were injected at the $\mathrm{S} 1$ level of adult mice once a day for $5 \mathrm{~d}$. Animals were allowed $2 \mathrm{~d}$ recovery and then were killed, and lumbar L4-L5 DRG was collected and processed for either immunochemistry or dissociation for time-lapse video microscopy and electrophysiological recordings. In preliminary experiments, intrathecal transfection efficiency was evaluated with a green fluorescent protein (GFP) siRNA tagged with rhodamine (Qiagen, Courtaboeuf, France) injected in an actin-GFP mice. Fluorescence analysis of rhodamine-tagged neurons on DRG slices demonstrated that $50-$ $80 \%$ of neurons were transfected with this method and that transfected neurons did not express GFP, evaluated as a lack of costaining between green GFP and red siRNA (data not shown).

Genotyping. This was performed using PCR on toe DNA. For $\mathrm{NKCC1}^{-1-}$ mice, primers for the mutant gene were forward $5^{\prime}$ TGCAACTGGTATTCTAGCTGGAGC- $3^{\prime}$ and reverse $5^{\prime}$-TACAACA CACACTCCAACCTCCG-3' and for control gene were forward $5^{\prime}$ TATCTCAGGTGATCTTGC- $3^{\prime}$ and reverse 5'-ACACTGCAA TTCCTATGTAAACC-3'.

Cell dissociation. Neuron cultures were established from lumbar (L4L5) DRG. Ganglia were successively treated by two incubations with collagenase A ( $1 \mathrm{mg} / \mathrm{ml}$; Roche Diagnostics, Meylan, France) for $45 \mathrm{~min}$ each at $37^{\circ} \mathrm{C}$ and then with $0.25 \%$ trypsin-EDTA (Sigma, St. Quentin Fallavier, France) for $30 \mathrm{~min}$. They were then mechanically dissociated, and isolated cells were collected by centrifugation, followed by suspension in neurobasal culture medium supplemented with 2\% B27 (Invitrogen), $2 \mathrm{~mm}$ glutamine, and penicillin/streptomycin $(20 \mathrm{U} / \mathrm{ml}, 0.2 \mathrm{mg} / \mathrm{ml}$; Sigma). Dissociated neurons were plated on D-polyornithine $(0.5 \mathrm{mg} /$ $\mathrm{ml})$-laminin $(5 \mu \mathrm{g} / \mathrm{ml})$-coated glass coverslips and kept at $35^{\circ} \mathrm{C}$ in an incubator with a humidified $95 \%$ air $/ 5 \% \mathrm{CO}_{2}$ atmosphere. Two hours after plating, the culture medium was carefully removed and replaced to eliminate dead cells and tissue debris. For survival experiments with bumetanide incubation, cells were counted 2 and $24 \mathrm{~h}$ after plating, using phase contrast under a Zeiss (Le Pecq, France) photonic microscope.

Electrophysiological recordings. The ionotropic $\mathrm{GABA}_{\mathrm{A}}$ current was recorded at $20-22^{\circ} \mathrm{C}$ using the gramicidin-perforated patch-clamp technique in DRG neurons after $1 \mathrm{~d}$ in vitro using an Axopatch 200B amplifier (Dipsi Industrie, Chatillon, France). The bath solution contained 140 mu tetraethylammonium (TEA)-Cl, 2 mM CaCl$, 1.5 \mathrm{~mm} \mathrm{MgCl}_{2}, 10 \mathrm{~mm}$ glucose, and $10 \mathrm{~mm}$ HEPES, at $\mathrm{pH} 7.4$ with $\mathrm{CsOH}$, and the pipette solution contained $30 \mathrm{~mm} \mathrm{CsCl}$ and $110 \mathrm{~mm}$ Cs-methanesulfonate, or $140 \mathrm{~mm}$ $\mathrm{CsCl}, 1.5 \mathrm{~mm}$ Mg-ATP, $0.5 \mathrm{~mm}$ Na-GTP, $0.1 \mathrm{~mm}$ EGTA, and $10 \mathrm{~mm}$ HEPES, at pH 7.35. To determine $\left[\mathrm{Cl}^{-}\right]_{\mathrm{i}}$, gramicidin A (Fluka, St. Quentin Fallavier, France) $(50 \mu \mathrm{g} / \mathrm{ml})$ was added to the pipette solution. The progress of gramicidin perforation was evaluated by on-line monitoring with pClamp version 8.2 software (Dipsi Industrie) the capacitive current transient produced by a $10 \mathrm{~ms}$ depolarizing voltage step $(10 \mathrm{mV})$ from a $-80 \mathrm{mV}$ holding potential. With $50 \mu \mathrm{g} / \mathrm{ml}$ gramicidin, the access resistance dropped to $30-40 \mathrm{M} \Omega$ within $15 \mathrm{~min}$ of seal formation (Kyrozis and Reichling, 1995). Puff application of muscimol (Sigma) activated a chloride current attributable to $\mathrm{GABA}_{\mathrm{A}}$ receptor activation. The $\left[\mathrm{Cl}^{-}\right]_{\mathrm{i}}$ was calculated using the following Nernst equation: $E_{\mathrm{rev}}=\mathrm{RT} /$ $\mathrm{ZF} \times\left(\log \left(\left[\mathrm{Cl}^{-}\right]_{\mathrm{i}} /\left[\mathrm{Cl}^{-}\right]_{\mathrm{e}}\right)\right.$, where $\mathrm{RT} / \mathrm{ZF}$ was $58 \mathrm{mV}$ at room temperature, and $\left[\mathrm{Cl}^{-}\right]_{e}$ was $147 \mathrm{~mm}$. The contribution of the $\mathrm{HCO}_{3}{ }^{-}$anion to $I_{\text {GABA-A }}$ was minimized by using HEPES-buffered solutions.

Video microscopy. For time-lapse video microscopy, neuronal cultures were observed with an inverted Zeiss Axiovert 200M equipped with a CCD camera (Micromax; Roper Scientific, Evry, France) and a motorized platine driven with MetaMorph 7.0 software (Molecular Devices, Downingtown, PA). Temperature and atmosphere were controlled $\left(37^{\circ} \mathrm{C}, 5 \% \mathrm{CO}_{2}\right)$. Neurons were seeded in four-well chambers at a density of 1000 neurons per well. At $2 \mathrm{~h}$ after plating, neurons were placed in the recording chamber and left to grow in the culture medium. Phasecontrast images of several neurons per well were collected with an LD A-Plan $20 \times / 0.3$ objective every $30 \mathrm{~min}$ for $24 \mathrm{~h}$ and analyzed off-line with the MetaMorph software. Neurite growth of each neuron was calculated as the length of a neurite reached each hour for $24 \mathrm{~h}$ and expressed as a velocity in micrometers per hour.

Total RNA isolation, reverse transcriptase-PCR, and real time reverse transcriptase-PCR. RNA of lumbar L4-L5 DRG was isolated and purified using the TriReagent solution (Sigma). cDNA synthesis was performed by reverse transcription with $100 \mathrm{U}$ of Superscript II reverse transcriptase (Invitrogen) and $5 \mu \mathrm{M}$ hexamer random primers (Roche Diagnostics), $0.5 \mathrm{~mm}$ of each dNTP, $10 \mathrm{~mm}$ of DTT, and $20 \mathrm{U}$ of RNase-OUT. PCR amplification was performed using $0.2 \mu \mathrm{M}$ of each primer, $10 \times$ PCR buffer, $0.2 \mathrm{~mm}$ of dNTP, $1.5 \mathrm{~mm}$ of $\mathrm{MgCl}_{2}$, and $0.5 \mathrm{U}$ of Platinum TaqDNA polymerase (Invitrogen). Negative control consisted of DNasetreated and non-reverse-transcribed total RNA. The reverse transcriptase (RT)-PCR product was identified by direct sequence analysis (Genome Express, Meylan, France). One set of specific primers for NKCC1 amplification was used: NKCC1 sense, 5' CATGGTGTCAGGATTTGCAC; and antisense, 5' CGTTCAATTCAGCAATCAGG. The expected length of resulting amplification product was $236 \mathrm{bp}$.

Real-time PCR was performed using SYBR Green I dye detection on the LightCycler system (Roche Diagnostics) as described previously (Mechaly et al., 2006). Briefly, PCRs were performed in glass capillaries in a $10 \mu \mathrm{l}$ volume containing $3 \mu \mathrm{l}$ of RT product (final dilution of 1:30), 0.5 $\mu \mathrm{M}$ of forward and reverse primers, and $5 \mu \mathrm{l}$ of QuantiTect SYBR Green PCR Master Mix (Qiagen). Negative control using water instead of template and/or non-reverse-transcribed RNA was performed simultaneously. After an initial activation step of $15 \mathrm{~min}$ at $95^{\circ} \mathrm{C}, 45$ cycles consisting of $94^{\circ} \mathrm{C}$ for $15 \mathrm{~s}, 55^{\circ} \mathrm{C}$ for $20 \mathrm{~s}$, and $72^{\circ} \mathrm{C}$ for $35 \mathrm{~s}$ were performed. The identity of RT-PCR amplified products was confirmed at least once by sequencing (Genome Express) and by routinely finishing PCR runs with a melting curve analysis $\left(70-95^{\circ} \mathrm{C}\right.$ at $0.2^{\circ} \mathrm{C}$ increments), allowing the melting behavior of amplicons to be verified. Primers used were the same as those used for RT-PCR. As described previously (Mechaly et al., 2006), the relative amounts of specifically amplified cDNAs were calculated using the $\Delta C T$ method on three independent exper- 
imental replicates and normalized by two stable control genes, Polr $2 \mathrm{j}$ and Ddx 48 , the expression of which does not change after axotomy.

Electrophoresis and Western blotting. Total proteins from lumbar L4-L5 DRG were prepared by addition of $100 \mu \mathrm{l}$ of PBS with protease inhibitors ( $60 \mathrm{~mm}$ sodium fluoride, $30 \mathrm{~mm}$ sodium pyrophosphate, 0.2 $\mathrm{mm}$ sodium orthovanadate, and $0.5 \mu \mathrm{M}$ calyculin A) and homogenized at $4^{\circ} \mathrm{C}$ using a Dounce homogenizer in $5 \mathrm{vol}$ of radioimmunoprecipitation assay buffer ( $50 \mathrm{~mm}$ Tris- $\mathrm{HCl}, \mathrm{pH} 7.5,150 \mathrm{~mm} \mathrm{NaCl}, 1 \%$ Triton X-100, $0.1 \%$ SDS, 2 mu EDTA, and $0.5 \%$ desoxycholic acid) containing protease and phosphatase inhibitors. Cellular debris and nuclei were removed by centrifugation at $14,000 \mathrm{rpm}$ for $20 \mathrm{~min}$ at $4^{\circ} \mathrm{C}$. Supernatants were collected, and total protein amounts were measured using the BCA assay method (Pierce). A total of $20 \mu \mathrm{g}$ of total protein of the lysate from control and axotomized DRG were diluted into $5 \times$ Laemmli's SDS sample buffer and boiled for $2 \mathrm{~h}$ at $40^{\circ} \mathrm{C}$. Loads of $20 \mu \mathrm{g}$ of protein per well were then separated by $10 \%$ SDS-PAGE ( $120 \mathrm{~V}$ for $1 \mathrm{~h} 30 \mathrm{~min})$. Proteins were then transferred ( $13 \mathrm{~V}$ for $1 \mathrm{~h} 30 \mathrm{~min}$ ) to Immobilon-P membranes (GE Healthcare, Little Chalfont, UK) and blocked with 5\% dry milk for $2 \mathrm{~h}$ at room temperature.

NKCC1 was detected with a T4 monoclonal antibody generated against a fusion protein fragment encompassing the C-terminus (S760 S1212) amino acid of the human colon NKCC1 (Developmental Studies Hybridoma Bank, University of Iowa, Iowa City, IA). The phosphorylated form of NKCC1 was detected using rabbit R5 polyclonal antibody (kindly provided by Dr. B. Forbush, Yale University, New Haven, CT) raised against a diphosphopeptide containing Thr212 and Thr217 of human NKCC1. Both primary antibodies T4 and R5 were used at the concentration of 1:1000 overnight at $4^{\circ} \mathrm{C}$. The following day, membrane were extensively washed with TBST buffer $[0.1 \%(\mathrm{v} / \mathrm{v})$ Tween $20,25 \mathrm{~mm}$ Tris, and $150 \mathrm{~mm} \mathrm{NaCl}, \mathrm{pH} 7.5$ ] and incubated for $1 \mathrm{~h}$ with a secondary antibody, either goat anti-mouse peroxidase conjugated or goat antirabbit peroxidase conjugated (1:5000; GE Healthcare). After washing with TBST, the immune complex was detected by BMChemiluminescence blotting substrate (POD) (Roche Diagnostics) on chemiluminescent film. Blots were reblotted with anti-actin antibody (Santa Cruz Biotechnology via Tebu, Le Perray en Yvelines, France) as a loading control.

Immunohistochemistry. Frozen transverse sections (14 $\mu \mathrm{m}$ thick) were prepared from adult lumbar L5 DRG fixed with $4 \%$ paraformaldehyde in PBS and cryopreserved in 25\% sucrose in PBS, before embedding in O.C.T. compound (Sakura Finetek, Zoeterwoude, The Netherlands). The sections were treated with 1\% SDS and 8\% 2-mercaptoethanol for 5 min and then washed in PBS and incubated with 15\% goat serum in PBS for $30 \mathrm{~min}$ at room temperature. Sections were then incubated overnight at $4^{\circ} \mathrm{C}$ with the R5 primary antibody against phospho-NKCC1 (1:500 in PBS) diluted in $0.3 \%$ goat serum. After washing the primary antibody with PBS, sections were incubated for $1 \mathrm{~h}$ at room temperature with a goat anti-rabbit secondary antibody conjugated with cyanine 3 (1:3000). Omission of the primary antibody or its replacement with rabbit nonimmune serum were used for control experiments. The slides were then washed in PBS before mounting with aqueous medium. Images were collected using a PL-Apochromat $20 \times / 0.8$ objective on a upright Zeiss microscope equipped with a CCD camera AxioCam MRm (Zeiss). Image acquisition and analysis were done using Axio Vision (Zeiss).

Statistical analysis. All data are expressed as the mean \pm SEM. Unpaired Student's $t$ test or one-way or two-way ANOVA when appropriate were used for comparison between groups for all experiments, except for quantitative RT (qRT)-PCR experiments (Mann-Whitney $U$ test). $p<$ 0.05 was considered statistically significant.

\section{Results \\ Peripheral nerve injury induces an increase in $\left[\mathrm{Cl}^{-}\right]_{\mathrm{i}}$ in sensory neurons}

Four to $10 \mathrm{~d}$ after an in vivo sciatic nerve section, dissociated axotomized neurons were selected according to their regenerative, elongated growth as was described previously after $1 \mathrm{~d}$ in vitro (Andre et al., 2003). This morphological criterion ensured that these neurons had been conditioned by a lesion (Smith and
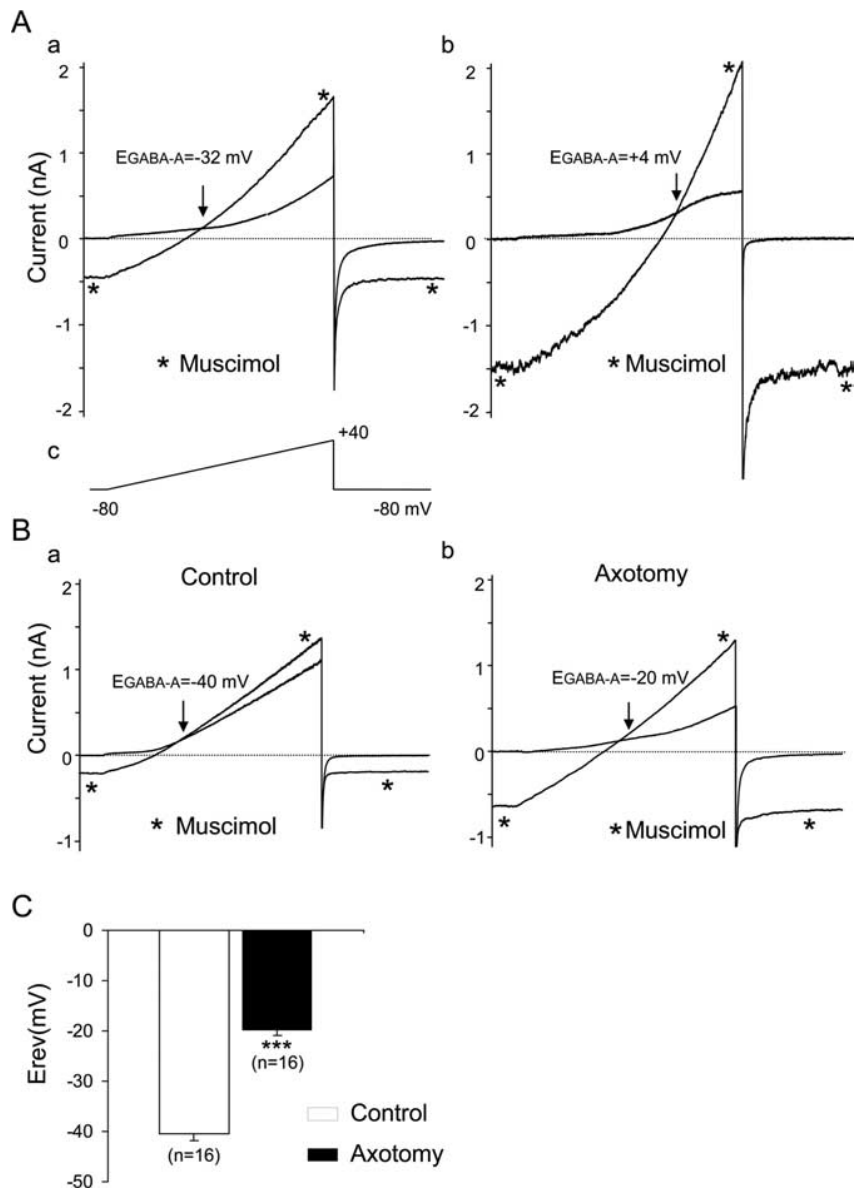

Figure 1. Reversal potential of $\mathrm{GABA}_{\mathrm{A}}$ receptor-mediated chloride current in control and axotomized mouse sensory neurons. $A$, Conventional whole-cell patch-clamp recordings with a patch electrode containing $30 \mathrm{~mm} \mathrm{Cl}^{-}(\boldsymbol{a})$ and $140 \mathrm{mM} \mathrm{Cl}^{-}(\boldsymbol{b})$. Ramp protocols from -80 to $+40 \mathrm{mV}$ were applied every $5 \mathrm{sin}$ a Na-free, K-free, $147 \mathrm{~mm}$ TEA-Cl extracellular solution (c). To reduce $\mathrm{Ca}^{2+}$ currents amplitude, $100 \mu \mathrm{m} \mathrm{NiCl}$ and $\mathrm{CdCl}_{2}$ were added. Under these experimental conditions, the voltage ramp elicited a small-amplitude outwardly rectifying conductance. Application of $100 \mu \mathrm{m}$ muscimol to activate the $\mathrm{GABA}_{\mathrm{A}}$ current induced an increase in slope conductance. Reversal potential of $\mathrm{GABA}_{\mathrm{A}}$ current, $E_{\mathrm{GABA}-\mathrm{A}}$, was determined at the intersection point between control and muscimol conductance. Consistent with a muscimol-induced chloride current, $E_{\mathrm{GABA}-\mathrm{A}}$ was $-32 \mathrm{mV}$ in $30 \mathrm{~mm}(\boldsymbol{a})$ and $+4 \mathrm{mV}$ in $140 \mathrm{~mm}$ intracellular $\mathrm{Cl}^{-}(\boldsymbol{b})$ in these neurons. $\boldsymbol{B}$, Gramicidin-perforated patch recordings were used to determine $\left[\mathrm{Cl}^{-}\right]_{\mathrm{i}}$. $E_{\text {GABA-A }}$ was $-40 \mathrm{mV}$ in a control neuron $(\boldsymbol{a})$ and $-20 \mathrm{mV}$ in an axotomized neuron $(\boldsymbol{b})$. $\boldsymbol{C}$, The mean $E_{\text {GABA-A }}$ in control was significantly less depolarized than in axotomized neurons $\left({ }^{* * *} p<\right.$ 0.001 , Student's $t$ test). The Nernst equation was used to calculate $\left[\mathrm{Cl}^{-}\right]_{\mathrm{i}}$, averaging $30.7 \pm 1.6$ $\mathrm{mm}, n=16$ and $68.4 \pm 3.2 \mathrm{~mm}, n=16$ in control and axotomized neurons, respectively.

Skene, 1997). The $\left[\mathrm{Cl}^{-}\right]_{\mathrm{i}}$ was determined by activating the ligand-gated $\mathrm{Cl}^{-}$channel $\mathrm{GABA}_{\mathrm{A}}$ receptor with muscimol. To measure the reversal potential of the muscimol-induced current, $E_{\mathrm{GABA}-\mathrm{A}}$, the external recording solution was designed to inhibit the $\mathrm{Na}^{+}, \mathrm{Ca}^{2+}$, and $\mathrm{K}^{+}$currents, which had the advantage of determining $E_{\mathrm{GABA}-\mathrm{A}}$ with a ramp protocol needing only one application of muscimol. Under whole-cell patch clamp with 30 or $140 \mathrm{~mm}$ intracellular $\mathrm{Cl}^{-}, E_{\mathrm{GABA}-\mathrm{A}}$ averaged $-33.0 \pm 2.2 \mathrm{mV}$, $n=7$ and $-0.4 \pm 4.6 \mathrm{mV}, n=10$, respectively, in control neurons (Fig. $1 A a, A b$ ). These values were close to the expected values for the reversal potential of chloride ions in a $147 \mathrm{~mm}$ external $\mathrm{Cl}^{-}\left(-40.0 \mathrm{mV}\right.$ for $30 \mathrm{~mm}$ internal $\mathrm{Cl}^{-} ;-1.2 \mathrm{mV}$ for $140 \mathrm{~mm}$ internal $\mathrm{Cl}^{-}$) and demonstrated the accuracy of our method of measurement. To estimate the actual $\left[\mathrm{Cl}^{-}\right]_{\mathrm{i}}$ in sensory neurons, we used the gramicidin-perforated patch-clamp method. Under these conditions, $E_{\mathrm{GABA}-\mathrm{A}}$ averaged $-39.9 \pm 1.3 \mathrm{mV}, n=16$ in 
control neurons. In axotomized neurons, $E_{\mathrm{GABA}-\mathrm{A}}$ was $-19.7 \pm$ $1.2 \mathrm{mV}, n=16$ (Fig. $1 B$ ). Thus, $E_{\text {GABA-A }}$ was significantly more depolarized in axotomized neurons compared with control (Fig. $1 C)(p<0.001)$.

Efflux of $\mathrm{HCO}_{3}{ }^{-}$through the anion pore can have a significant contribution to the measurement of the reversal potential of $I_{\text {GABA-A }}$ (Kaila and Voipio, 1987). Although our recording conditions were designed to minimize such contribution, we performed a series of experiments in which a low external chloride solution was used to evaluate the contribution of $\mathrm{Cl}^{-}$ions to $I_{\text {GABA-A }}$. To deplete intracellular $\mathrm{Cl}^{-}$, axotomized neurons were incubated overnight in a solution containing $5 \mathrm{mM} \mathrm{Cl}^{-}$ions instead of $147 \mathrm{~mm}$. Afterward, $E_{\mathrm{GABA}-\mathrm{A}}$ measurements were performed in the standard recording solution. Under these experimental conditions, $E_{\mathrm{GABA}-\mathrm{A}}$ averaged $-33.0 \pm 0.7 \mathrm{mV}, n=6$, suggesting that $\mathrm{Cl}^{-}$ions are the main contributors of $I_{\mathrm{GABA}-\mathrm{A}}$ recorded in axotomized neurons (data not shown).

We calculated $\left[\mathrm{Cl}^{-}\right]_{\mathrm{i}}$ in each neuron based on the Nernst equation using $E_{\mathrm{GABA}-\mathrm{A}}$ and the $\left[\mathrm{Cl}^{-}\right]_{\mathrm{e}}$ set to $147 \mathrm{~mm}$ in the extracellular solution (see Materials and Methods). $\left[\mathrm{Cl}^{-}\right]_{\mathrm{i}}$ values were $30.7 \pm 1.6 \mathrm{~mm}$ in control neurons $(n=16)$ and $68.4 \pm 3.2$ mM in axotomized neurons $(n=16)$. The increase in $\left[\mathrm{Cl}^{-}\right]_{\mathrm{i}}$ was observed in axotomized neurons regardless of their somatic size. Moreover, pretreatment with a low external $\mathrm{Cl}^{-}$solution induced a decrease in $\left[\mathrm{Cl}^{-}\right]_{\mathrm{i}}$ to $40.0 \pm 2.3 \mathrm{~mm}, n=6$, in axotomized neurons.

These data reveal that a conditioning sciatic nerve injury promotes an increase in $\left[\mathrm{Cl}^{-}\right]_{\mathrm{i}}$ of axotomized sensory neurons in vitro.

\section{NKCC1 is responsible for $\left[\mathrm{Cl}^{-}\right]_{\mathrm{I}}$ increase in axotomized neurons}

To determine whether NKCC1 is responsible for the increase in $\left[\mathrm{Cl}^{-}\right]_{\mathrm{i}}$ in sensory neurons after a peripheral nerve section, we first used a pharmacological inhibitor of NKCC1, the diuretic bumetanide. Pretreatment of sensory neurons with $10 \mu \mathrm{M}$ bumetanide, $1 \mathrm{~h}$ before cell recordings, induced a shift in the reversal potential of $I_{\mathrm{GABA}-\mathrm{A}}$ toward a slightly more negative value in control neurons $(-46.7 \pm 1.5 \mathrm{mV} ; n=10 ; p<0.001$ compared with the control value). In axotomized neurons, bumetanide reduced $\left[\mathrm{Cl}^{-}\right]_{\mathrm{i}}$ increase. Under these conditions, $E_{\mathrm{GABA}-\mathrm{A}}$ was $-36.4 \pm$ $1.4 \mathrm{mV}, n=10$, significantly hyperpolarized relative to nontreated axotomized neurons $(p<0.001)$ (Fig. $2 A)$. Under bumetamide treatment, the increase in $\left[\mathrm{Cl}^{-}\right]_{\mathrm{i}}$ amounted $11 \mathrm{~mm}$ $(p<0.001)$ instead of $38 \mathrm{~mm}$.

To ensure that the increase in $\left[\mathrm{Cl}^{-}\right]_{\mathrm{i}}$ after nerve injury is related to the NKCC1 cotransporter, we next performed gramicidin-perforated patch recordings in sensory neurons from $\mathrm{NKCC1}^{-/-}$mice. As reported previously (Sung et al., 2000), the $E_{\mathrm{GABA}-\mathrm{A}}$ was slightly more hyperpolarized in $\mathrm{NKCC1}^{-1-}$ mice compared with wild type. The reversal potential averaged $-41.3 \pm 1.9 \mathrm{mV}$ in wild-type C57BL/ 6 mice $(n=6)$ and $-50.3 \pm$ $1.5 \mathrm{mV}, n=11$, in $N K C C 1^{-1-}$ mice, which corresponds to an $\left[\mathrm{Cl}^{-}\right]_{\mathrm{i}}$ of $29.2 \pm 2.6$ and $20.4 \pm 1.3 \mathrm{~mm}$, respectively (Fig. $2 \mathrm{~B}$ ) $(p<0.001)$. In axotomized neurons from $\mathrm{NKCC1}^{-1-}$ mice, the increase in $\left[\mathrm{Cl}^{-}\right]_{\mathrm{i}}$ was nearly abolished. The reversal potential averaged $-20.1 \pm 1.8 \mathrm{mV}, n=7$, in wild-type mice and $-41.4 \pm$ $1.9 \mathrm{mV}$ in $\mathrm{NKCC}^{-1-}$ mice, $n=11(p<0.001)$, which corresponded to $\left[\mathrm{Cl}^{-}\right]_{\mathrm{i}}$ of $67.1 \pm 4.9$ and $29.3 \pm 2.1 \mathrm{mM}$, respectively (Fig. $2 \mathrm{~B}$ ). Thus, in $\mathrm{NKCC1}^{-1-}$ mice neurons, the basal $\left[\mathrm{Cl}^{-}\right]_{\mathrm{i}}$ was significantly decreased by $9 \mathrm{~mm}$ compared with their control littermate, and the increase in $\left[\mathrm{Cl}^{-}\right]_{\mathrm{i}}$ after injury amounted $9 \mathrm{~mm}$ $(p<0.001)$ instead of $38 \mathrm{~mm}$ and was not significantly different
A

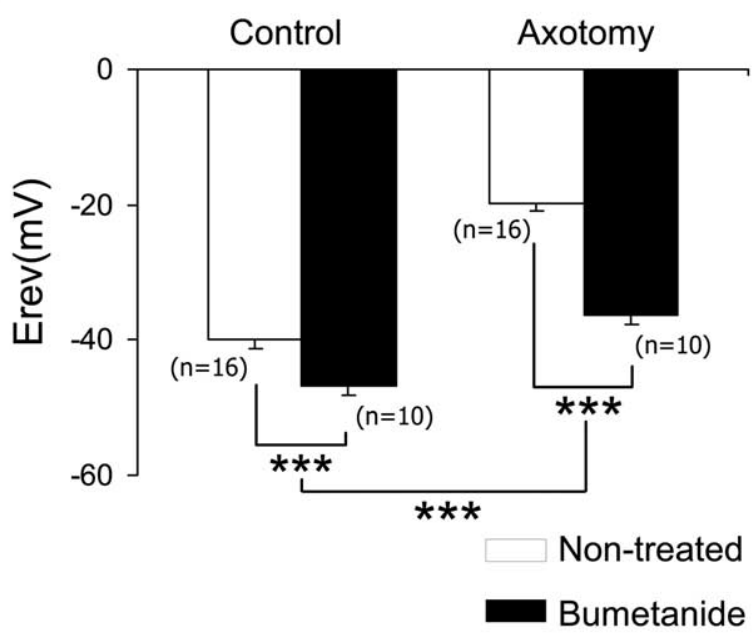

B

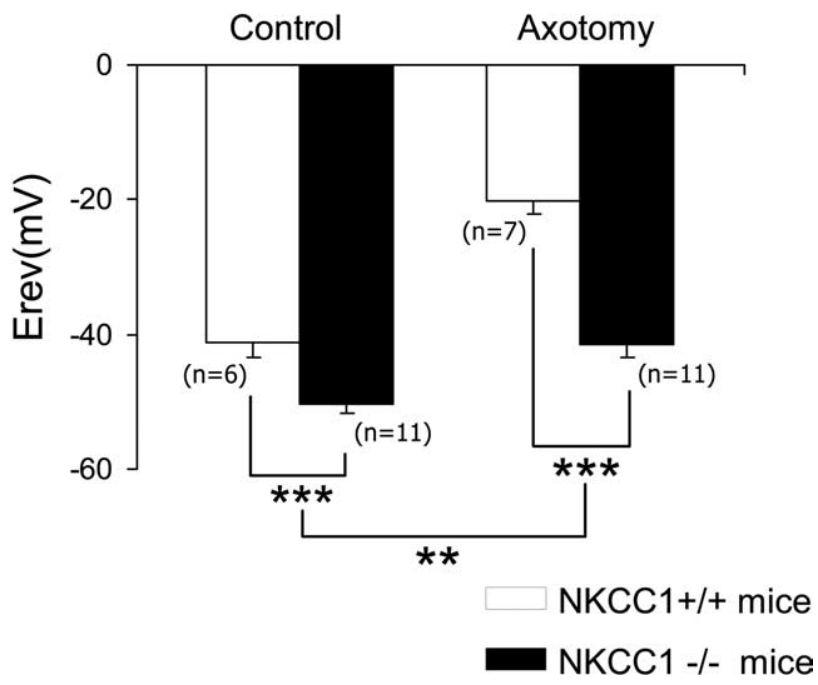

Figure 2. NKCC1 is responsible for $\left[\mathrm{Cl}^{-}\right]_{i}$ increase in axotomized neurons. $A$, Neuronal cultures pretreated for $1 \mathrm{~h}$ with $10 \mu \mathrm{m}$ bumetanide showed a shift of $E_{\text {GABA-A }}$ toward hyperpolarized values in both control and axotomized neurons, and the main effect of bumetanide was associated with axotomy. $E_{\text {GABA-A }}$ remains significantly more depolarized in bumetanidetreated axotomized neurons than in bumetanide-treated control neurons $(p<0.001$; data not shown). $\boldsymbol{B}$, Analysis of the $\mathrm{NKCC}^{-1-}$ mouse demonstrated a shift in $E_{\text {GABA-A }}$ toward hyperpolarized values in control and axotomized neurons, and the main effect of NKCC1 deletion was associated with axotomy. $E_{\mathrm{GABA}-\mathrm{A}}$ remains significantly more depolarized in $\mathrm{NKCC}^{-1-}$ axotomized neurons than in $N K C C 1^{-1-}$ control neurons ( $p<0.001$; data not shown). ${ }^{* *} p<0.01$, ${ }^{* * *} p<0.001$, two-way ANOVA.

from bumetanide-treated axotomized neurons $(p<0.05$, oneway ANOVA).

Because bumetanide is reported to inhibit other transporters and also $\mathrm{GABA}_{\mathrm{A}}$ receptors (Sung et al., 2000) and because adult knock-out mice may develop functional compensatory effects, we confirmed the involvement of NKCCl in the control of $\left[\mathrm{Cl}^{-}\right]_{\mathrm{i}}$ in axotomized neurons by using RNA interference for gene silencing. We performed a series of experiments in which NKCC1 was inhibited by intrathecal injections of NKCC1 siRNA for $5 \mathrm{~d}$ (see Materials and Methods). On day 3 of injection, the left sciatic nerve was sectioned, and, $4 \mathrm{~d}$ later, L4-L5 DRG were removed and cell cultures were prepared. To examine the specificity and 
A

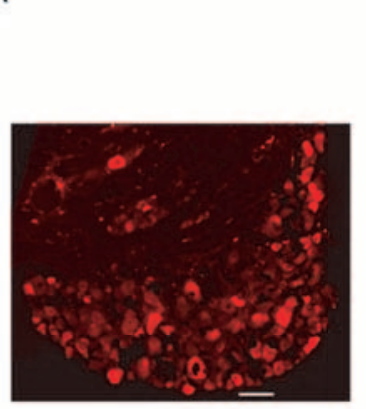

B

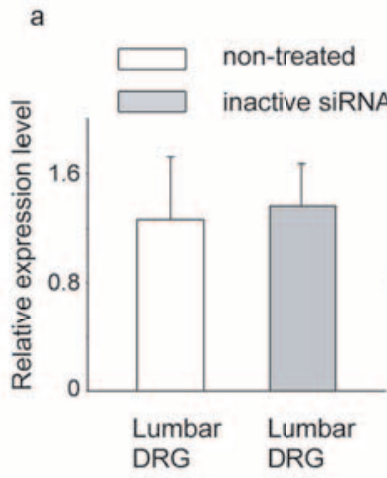

b

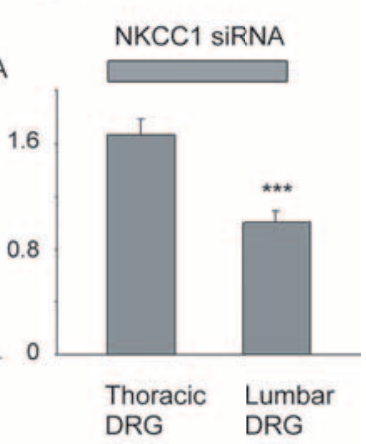

C

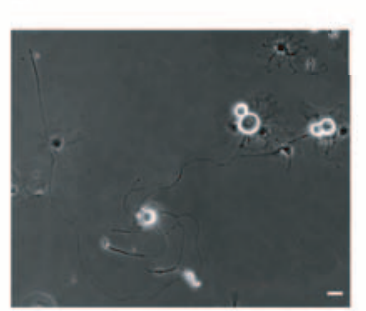

b

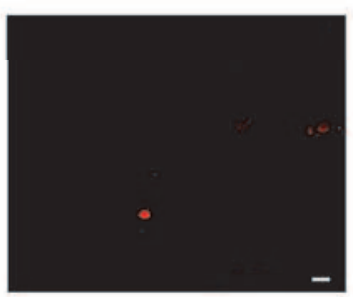

C

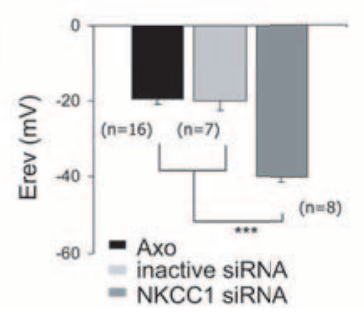

Figure 3. NKCC1 is responsible for $\left[\mathrm{Cl}^{-}\right]_{\mathrm{i}}$ increase in axotomized neurons. Gene inhibition of NKCC1 was achieved after NKCC1 siRNA/dextran-rhodamine intrathecal injection. Transfection was estimated by visualization of fluorescent neurons in DRG or in culture. $\boldsymbol{A}$, Neuron counting in a slice of L5 DRG shows a near $40 \%$ of bright fluorescent neurons. Scale bar, $100 \mu \mathrm{m} . \boldsymbol{B}, \mathrm{qRT}-\mathrm{PCR}$ analysis of NKCC1 transcripts in lumbar and thoracic DRG. $\boldsymbol{a}$, Control siRNA-injected mice shows similar level of NKCC1 transcripts than noninjected mice $(n=4)$. $\boldsymbol{b}$, Intrathecal injection of NKCC1 siRNA demonstrates the decrease in NKCC1 transcripts in lumbar compared with thoracic DRG $\left(n=4 ;^{* * *} p<0.001\right.$, Mann-Whitney U test). C, Phase-contrast photograph of axotomized neurons at $1 \mathrm{~d}$ in vitro from L4 - L5 DRG after intrathecal siRNA/dextran injection (a). Half of these neurons express rhodamine fluorescence (red) $(\boldsymbol{b})$. Scale bar, $20 \mu \mathrm{m}$. Recordings of $\left[\mathrm{Cl}^{-}\right]_{\mathrm{i}}$ with the gramicidin-perforated patch-clamp method demonstrating that most of the fluorescent axotomized neurons showed $E_{G A B A-A}$ to be significantly more hyperpolarized in NKCC1 siRNA than in control siRNA-treated animals $(\boldsymbol{c}) .{ }^{* * *} p<0.001$, one-way ANOVA.

efficiency of NKCC1 siRNA injection on gene expression, we performed real-time RT-PCR and functional analysis of NKCC1 by electrophysiological measurements of $\left[\mathrm{Cl}^{-}\right]_{\mathrm{i}}$. Evaluation of the percentage of transfected neurons was done by counting rhodamine-labeled neurons on DRG sections. Figure $3 A$ shows the percentage of labeled neurons in a L5 DRG that varied between 40 and 50\%. To ensure the effectiveness of NKCC1 siRNA, gene expression of NKCC1 was compared in noninjected mice, in mice with intrathecal injection of control siRNA, and mice injected with the NKCC1 siRNA (Fig. $3 B a, B b$ ). Although PEIdelivered siRNA-negative control did not significantly modify NKCC1 mRNA compared with control (Fig. 3Ba), PEI-delivered siRNA NKCC1 resulted in $40 \pm 3 \%(n=4)$ decrease of NKCC1 mRNA in lumbar DRG compared with thoracic DRG (Fig. 3Bb), demonstrating the efficiency of the NKCC1 siRNA pool close to the site injection (S1 level).

Efficiency of the cotransfection of dextran and siRNA and validation of NKCC1 as being responsible for $\mathrm{Cl}^{-}$accumulation in axotomized neurons were analyzed at the functional protein level by electrophysiological recordings of $\left[\mathrm{Cl}^{-}\right]_{\mathrm{i}}$. Primary cultures were composed of rhodamine-labeled and nonlabeled neurons (Fig. 3Ca,Cb). Experiments performed on control siRNAtreated mice showed that rhodamine-labeled axotomized neurons had an $E_{\mathrm{GABA}-\mathrm{A}}$ not significantly different from nontreated axotomized neurons $(-20.1 \pm 2.5 \mathrm{mV}, n=7$ compared with $-19.7 \pm 1.2 \mathrm{mV}, n=16$, respectively). Recordings from
NKCC1 siRNA-treated mice demonstrated a significant decrease in $E_{\mathrm{GABA}-\mathrm{A}}$ of axotomized neurons compared with control siRNA-injected animals $(-40.0 \pm 1.4$ $\mathrm{mV}, n=8$ compared with $-20.1 \pm 2.5$ $\mathrm{mV}, n=7$, respectively; $p<0.001$ ) (Fig. $3 C c)$.

Altogether, these data clearly demonstrate that NKCC1 is responsible for the increase in $\left[\mathrm{Cl}^{-}\right]_{\mathrm{i}}$ induced by nerve injury.

\section{NKCC1 phosphorylation is essential for $\left[\mathrm{Cl}^{-}\right]_{\mathrm{i}}$ increase}

To elucidate the molecular mechanisms leading to the increase in $\left[\mathrm{Cl}^{-}\right]_{\mathrm{i}}$ after peripheral nerve injury, we first analyzed the changes in transcriptional level of NKCC1 in whole DRG. NKCC1 transcript was detected in control and in axotomized DRG (Fig. 4A). Real-time RT-PCR analysis showed no significant change at the transcriptional level of NKCC1 cotransporter after axotomy (Fig. 4B). From these data, it appeared that $\left[\mathrm{Cl}^{-}\right]_{\mathrm{i}}$ increase could be related to an increase in the activity of the cotransporter NKCC1. Actually, the NKCC1 cotransporter is phosphorylated under a variety of conditions, and phosphorylation of threonine residues leads to an increase in its activity (Flemmer et al., 2002). To test the possibility of NKCC1 phosphorylation being the molecular basis for $\left[\mathrm{Cl}^{-}\right]_{\mathrm{i}}$ increase, we first analyzed the total protein expression of NKCC1 with the T4 antibody and then phosphorylated expression of NKCC1 with the phosphospecific antibody R5. We show that axotomy does not change the total amount of NKCC1 in whole DRG but promotes phosphorylation of NKCC1 (Fig. 4C).

To further analyze the cellular distribution of phosphoNKCC1 in the DRG, immunohistochemistry was performed on DRG slices (a phospho-NKCC1 signal could not be resolved in primary cultures). To analyze specific staining of R5, we used DRG from $\mathrm{NKCC1}^{-/-}$mice. Compared with the null staining in $\mathrm{NKCC1}^{-/-}$mice, a weak phospho-NKCC1 staining was observed in control DRG (Fig. 5A, B). After nerve injury, a strong R5 staining was observed in the cytoplasm and at the neuron membrane (Fig. 5C).

Altogether, these data demonstrate that nerve injury induces an increase in phosphorylation of NKCC1 in sensory neurons. At the functional level, many studies have established that phosphorylation of NKCC1 at threonine sites increases its activity, measured as an increase in $\left[\mathrm{Cl}^{-}\right]_{\mathrm{i}}$ (Lytle, 1997; Flemmer et al., 2002). To test this hypothesis in sensory neurons, we checked whether the cellular phosphorylation-dephosphorylation state could change $\left[\mathrm{Cl}^{-}\right]_{\mathrm{i}}$ in sensory neurons. On one hand, control neurons were incubated for $15 \mathrm{~min}$ with $20 \mathrm{~nm}$ calyculin $\mathrm{A}$, a potent protein phosphatase inhibitor 1 that promotes NKCC1 phosphorylation (Lytle, 1997). This treatment induced a depolarization in $E_{\mathrm{GABA}-\mathrm{A}}$ to $-21.6 \pm 5.4 \mathrm{mV}, n=10$, which corresponded to an increase in $\left[\mathrm{Cl}^{-}\right]_{\mathrm{i}}$ amounting to $63.6 \pm 12.9 \mathrm{~mm}$, a value close to those recorded in conditioned regenerating neurons. In contrast, incubation of axotomized sensory neurons with 
A

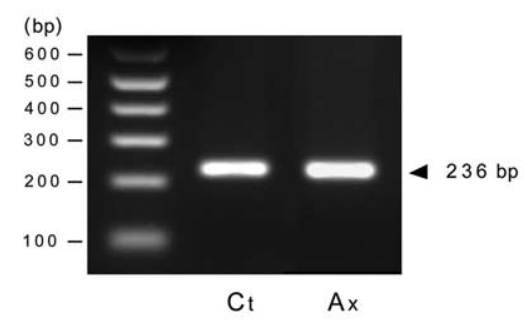

C

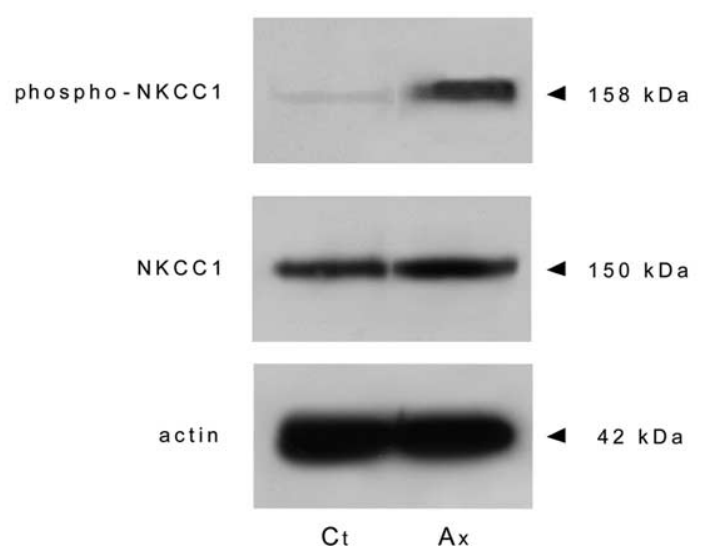

Figure 4. Nerve injury induces NKCC 1 phosphorylation. A, RT-PCR was performed on control and axotomized DRG. The NKCC1 primer amplified a product of the expected size (236 bp) in control ( $\mathrm{Ct}$ ) and axotomized (Ax) DRG whose molecular identity was confirmed by sequencing. $B$, qRT-PCR analysis of NKCC1 transcript levels in lumbar L4 -L5 DRG from control and axotomized mice shows that peripheral nerve injury does not quantitatively modify NKCC1 mRNA $(n=3)$. C, Western blot of protein expression with T4 (NKCC1) and R5 (phospho-NKCC1) antibodies shows an increase in protein phosphorylation in axotomized DRG. SDS-PAGE was conducted using $20 \mu \mathrm{g}$ of protein extract from uninjured DRG (control) and $5 \mathrm{~d}$ after sciatic nerve section (axotomized DRG). The apparent molecular size markers are indicated on the right. The same extracts were probed for $\beta$-actin.

$20 \mathrm{nM}$ staurosporine, a kinase inhibitor with broad selectivity, reduced the depolarization of $E_{\mathrm{GABA}-\mathrm{A}}$ to $-29.8 \pm 2.8 \mathrm{mV}, n=7$ ( $p<0.001$ compared with nontreated axotomized neurons),

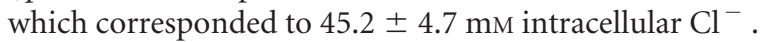

\section{NKCC1 increases neurite growth velocity of regenerating neurons}

As shown previously, the regenerative growth of axotomized neurons in vitro was characterized by an elongated, sparsely branched $(<1.5$ branches per $100 \mu \mathrm{m})$ neurite growth. Contrary to axotomized neurons, control growth was characterized by $>1.5$ branches per $100 \mu \mathrm{m}$ or had neurites shorter than one cell diameter (Andre et al., 2003). The percentage of axotomized neurons accounted for $\sim 60 \%$ of neuronal population in primary culture from L4-L5 DRG, and the morphological characteristic of elongated growth was used for off-line analysis of axotomized neuron neurite growth. The role of $\mathrm{NKCC} 1$ on the regenerative process was evaluated with time-lapse video microscopy, allowing the measurement on-line of the initiation and the velocity of the elongated regenerative neuritic growth in vitro (Fig. 6Aa,Ab) (supplemental movie, available at www.jneurosci.org as supplemental material). As shown in Figure 6A, neurite initiation measured as a neurite length longer than one cell diameter was evaluated $7 \mathrm{~h}$ after plating. The percentage of neurons displaying neurite initiation was significantly higher in axotomized neurons [54.0 $\pm 3.8 \%, n=8$ wells (276 total neurons) compared with $8.6 \pm 3.0 \%, n=8$ wells ( 245 total neurons) in control $(p<$ 0.001 ] (Fig. $6 B$ ). Moreover, neurite growth velocity was significantly increased in elongated axotomized neurons (48.5 \pm 6.7 $\mu \mathrm{m} / \mathrm{h}, n=45$ compared with $24.8 \pm 4.3 \mu \mathrm{m} / \mathrm{h}, n=43$ in control; $p<0.001$ ) (Fig. 6C).

In the presence of bumetanide, growth velocity was not significantly different in control neurons $(23.0 \pm 3.0 \mu \mathrm{m} / \mathrm{h}$; data not shown) but showed a significantly lower increase in axotomized neurons $(32.0 \pm 4.0 \mu \mathrm{m} / \mathrm{h}, n=40)$ (Fig. $7 A)$. Moreover, the percentage of axotomized neurons with neurite initiation, at $7 \mathrm{~h}$, was decreased under bumetanide treatment [36.8 $\pm 4.4 \%, n=8$ wells (240 total neurons); $p<0.001$; data not shown] but remained higher than in control neurons $(p<0.01)$. This effect of bumetanide on neurite initiation is probably unrelated to NKCC1 inhibition (see below). Despite inducing a neurite growth velocity in axotomized neurons similar to control neurons and decreasing the percentage of neurons showing neurite initiation, bumetanide did not change the elongated mode of growth in axotomized neurons. Cell counting indicated that bumetanide did not induce cell death until $72 \mathrm{~h}$ in either control or axotomized neurons (three cultures; data not shown).

To see whether intracellular $\mathrm{Cl}^{-}$ions were involved in neurite initiation and growth after axotomy, intracellular $\mathrm{Cl}^{-}$was depleted by incubating axotomized neurons in a solution containing $12 \mathrm{mM} \mathrm{Cl}^{-}$ions instead of $150 \mathrm{~mm}$. Under these conditions, growth velocity was significantly decreased compared with normal Cl${ }^{-}$conditions $(34.0 \pm 7.3 \mu \mathrm{m} / \mathrm{h}, n=31$ compared with $59.2 \pm 10.1 \mu \mathrm{m} / \mathrm{h}, n=29 ; p<0.001$ ) (Fig. $7 B$ ). Contrary to bumetanide, the percentage of neurons with neurite initiation remained unchanged compared with normal external $\mathrm{Cl}^{-}$concentration [ $63.7 \pm 4.9 \%, n=8$ wells ( 230 total neurons) in low external $\mathrm{Cl}^{-}$concentration]. These data suggest that regulation of intracellular chloride concentration is an important factor involved in the regenerative growth velocity.

Analysis of neurite growth in C57BL/6 mice shows that the elongated mode of growth induced by peripheral nerve injury remains in the $\mathrm{C} 57 \mathrm{BL} / 6$ mice $\left(\mathrm{NKCC1}^{+/+}\right)$and in the genetically modified mice $\left(\mathrm{NKCC1}^{-/-}\right)$. Growth velocity of axotomized neurons from $\mathrm{NKCC} 1^{+/+}$mice was $49.6 \pm 7.6 \mu \mathrm{m} / \mathrm{h}, n=15$. In $N K C C 1^{-/-}$neurons, growth velocity was significantly decreased compared with $N K C C 1^{+/+}$mice $(30.5 \pm 8.7 \mu \mathrm{m} / \mathrm{h} ; n=40 ; p<$ 0.001) (Fig. 7C). Contrary to bumetanide, neurite initiation in axotomized neurons from $\mathrm{NKCC1^{-1- }}$ mice was not significantly different from that of wild-type mice $[48.7 \pm 5.3 \%, n=6$ wells (180 total neurons 180)].

When using NKCC1 silencing with RNA interference, timelapse recordings were performed on both rhodamine-labeled and nonfluorescent neurons. First, the effects of the intrathecal injection protocol on the growth velocity of axotomized neurons were evaluated with control siRNA. The neurite growth velocity of $56.3 \pm 13.3 \mu \mathrm{m} / \mathrm{h}, n=10$, in labeled axotomized neurons was not significantly different from nontreated axotomized neurons. In vivo pretreatment with NKCC1 siRNA induced a significant decrease in growth velocity of fluorescent axotomized neurons to $28.5 \pm 12.5 \mu \mathrm{m} / \mathrm{h}, n=36$ (Fig. 7D), but did not modify growth velocity in nonfluorescent axotomized neurons $51.9 \pm 4.0 \mu \mathrm{m} / \mathrm{h}$, $n=16$ (data not shown). Neurite initiation of axotomized neurons was not significantly changed by NKCC1 siRNA transfection $[40.5 \pm 10.7 \% ; n=6$ wells (200 total neurons)]. As with bumetanide and in $\mathrm{NKCC1}^{-/-}$mice, elongated mode of growth was unchanged with this NKCC1 knockdown strategy. Alto- 
A

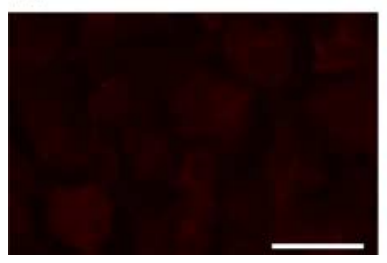

B
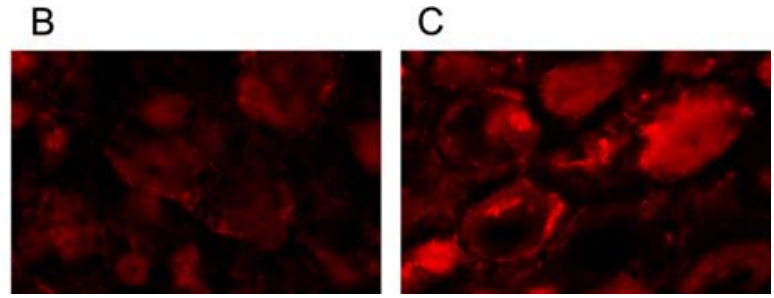

Figure 5. Phospho-NKCC1 immunohistochemistry in adult DRG. Phospho-NKCC1 protein expression was studied by immunohistochemistry using the rabbit polyclonal antibody $\mathrm{R} 5$ directed against a diphosphopeptide containing Thr212 and Thr217. A, R5 staining in DRG from NKCC1 $1^{-/-}$mice is used as negative control for specific staining. $\boldsymbol{B}$, Control DRG neurons show a weak staining of phospho-NKCC1 (red) in their cytoplasm and at the cell membrane. $\boldsymbol{C}$, At $5 \mathrm{~d}$ after peripheral nerve injury, intense R5 staining is expressed in sensory neurons. The R5 signal (red) is located in the cytoplasm and at the cell membrane. Scale bar, 50 $\mu \mathrm{m}$.

gether, these data demonstrate that axotomized neurons treated with bumetanide, a low external $\mathrm{Cl}^{-}$solution, $\mathrm{NKCC} 1$ siRNA, or from $\mathrm{NKCC1}^{-/-}$mice display a similar growth velocity of $\sim 30$ $\mu \mathrm{m} / \mathrm{h}$, i.e., a value close to control growth ( $p>0.05$, one-way ANOVA).

\section{Discussion}

The present study demonstrates that peripheral nerve injury leads to a substantial accumulation of $\mathrm{Cl}^{-}$in sensory neurons, which undergo a twofold to threefold fold increase in their $\left[\mathrm{Cl}^{-}\right]_{\mathrm{i}}$. Injury promotes phosphorylation of NKCC1, leading to increased activity without a change in transcript expression. Moreover, with the use of pharmacological inhibition, specific gene silencing with RNA interference, and $\mathrm{NKCC1}^{-/-}$mice, we show for the first time that this increase in intracellular chloride is
A

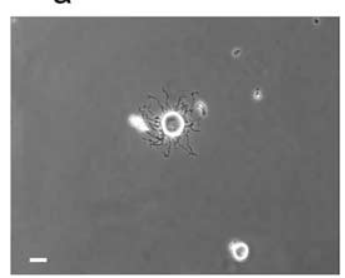

B
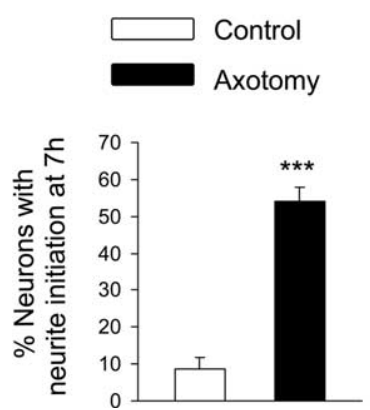

b

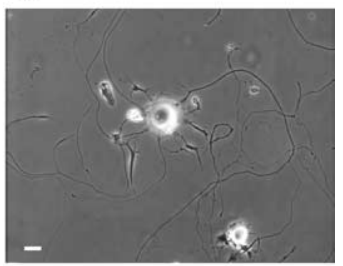

C
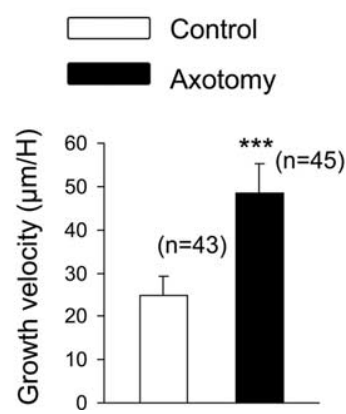

Figure 6. Analysis of the regenerative neurite growth. Time-lapse video microscopy was used to analyze the neuritic growth velocity of control and axotomized sensory neurons. $\boldsymbol{A}$, Phase-contrast photograph showing neurons from a sciatic nerve injury conditioned culture $3 \mathrm{~h}$ (a) and $24 \mathrm{~h}(\boldsymbol{b})$ after plating. Scale bar $20 \mu \mathrm{m}$. B , Neurite initiation was evaluated $7 \mathrm{~h}$ after plating and estimated as a neurite length longer than one cell diameter. The total number of neurons counted per well ranged in between 20 and 30; eight wells were analyzed per conditions. The percentage of neurons having initiated neurite growth was significantly greater after an axotomy. C, Growth velocity, estimated as the length of a neurite measured each hour for $24 \mathrm{~h}$, is significantly faster in axotomized neurons compared with control neurons. ${ }^{* * *} p<$ 0.001 , Student's $t$ test. involved in determining the velocity of regenerative neurite growth observed in vitro after a peripheral nerve injury in vivo.

It has been well established that sensory neurons display an earlier and enhanced pattern of neurite extension after a preconditioning injury in vivo compared with intact cells (Smith and Skene, 1997; Lankford et al., 1998; Andre et al., 2003). Elongated growth of neurons conditioned by in vivo sciatic nerve section, characterized by long, sparsely branched neurites, is a hallmark of the process of regeneration. In addition to these morphological analyses, we report that neurite growth initiation and velocity are faster in axotomized neurons than in control. There is an increasing amount of data aimed at identifying the factors responsible for efficient nerve regeneration. Among these factors, members of the gp130 family of cytokines as well the activating transcription factor 3 have been shown to be capable of recapitulating elongated growth and promoting neurite outgrowth (Cafferty et al., 2001; Seijffers et al., 2006). Our study adds a new dimension to this growing list of potential candidates by showing that chloride homeostasis and NKCC1 are also key elements involved in regeneration. Indeed, chloride homeostasis controls the velocity, but not the initiation or the mode, of elongated growth, pointing to the complexity of regenerative growth.

$\mathrm{Cl}^{-}$accumulation is the result of a decrease in outwardly directed $\mathrm{Na}^{+}$-independent $\mathrm{K}-\mathrm{Cl}$ cotransporters of the KCC family and/or the increase of inwardly directed $\mathrm{Na}-\mathrm{K}-\mathrm{Cl}$ cotransporters. An increase in $\left[\mathrm{Cl}^{-}\right]_{\mathrm{i}}$ attributed to downregulation of KCC2, a neuronal-specific isoform of the KCC family, has been reported in different types of adult central neurons after injury (Nabekura et al., 2002; Coull et al., 2003; Payne et al., 2003). In addition to NKCC1, members of the KCC (1-4) family are also expressed in sensory neurons. To date, Western blot analysis and immunostaining experiments have unequivocally identified KCC4 as being expressed in adult DRG (Karadsheh et al., 2004). We also detected KCC4 expression in DRG at the transcriptional level (our unpublished data), and a decrease in the activity of this cotransporter could contribute to the increase in $\left[\mathrm{Cl}^{-}\right]_{\mathrm{i}}$ that we report after an injury. Our experiments with both pharmacological inhibition of NKCC1 with low concentration of bumetanide as well the use of knockdown strategies using $\mathrm{NKCC1}^{-/-}$mice or in vivo injection of NKCC1 siRNA strongly suggest that the main factor leading to $\left[\mathrm{Cl}^{-}\right]_{\mathrm{i}}$ increase in axotomized sensory neurons is an increased activity of NKCC1. Besides the important lack of $\left[\mathrm{Cl}^{-}\right]_{\mathrm{i}}$ increase observed in bumetanide-treated neurons and in $\mathrm{NKCC} 1^{-1-}$ mice, there remains a minor but significant increase in $\left[\mathrm{Cl}^{-}\right]_{\mathrm{i}}$ under both conditions after axotomy. This effect could result from a downregulation of KCC induced by axotomy and contributing to the overall increase in $\left[\mathrm{Cl}^{-}\right]_{\mathrm{i}}$.

Contrary to the transcriptional regulation of KCC2 in central neurons, injury does not promote a change in NKCC1 transcript levels or in protein expression in peripheral neurons. Actually, our study demonstrates that there is an increase in the phosphorylated form of NKCC1 in sensory neurons after a nerve injury, as measured with Western blot and immunofluorescence with a specific phospho-NKCC1 antibody (Flemmer et al., 2002). In a recent work, an increase in phospho-NKCC1 was induced at central afferent terminal endings by a noxious visceral stimulus, confirming the posttranscriptional regulation of NKCC1 in sensory 
A

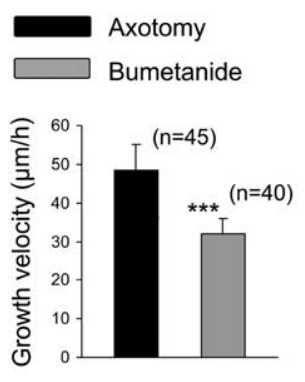

C
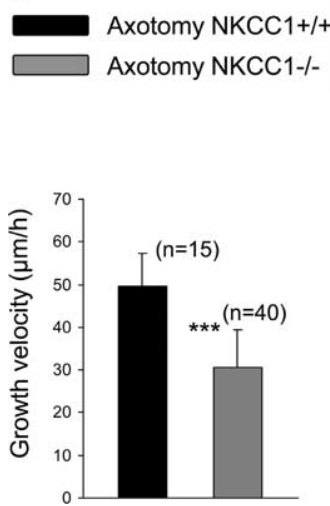

Figure 7. $\mathrm{NKCC} 1$ is involved in the regenerative neurite growth. $\boldsymbol{A}$, Bumetanide at $10 \mu \mathrm{M}$ was added $2 \mathrm{~h}$ after plating, and the culture was processed for time-lapse microscopy. Bumetanide treatment significantly decreased growth velocity of regenerating neurons. $\boldsymbol{B}$, Axotomized neuron growth velocity was significantly decreased when recorded in a low external $\mathrm{Cl}^{-}$ solution (in mM: $140 \mathrm{Na}$-methanesulfonate, $2 \mathrm{CaCl}_{2}, 1.5 \mathrm{MgCl}_{2}, 5 \mathrm{KCl}, 10$ glucose, and $10 \mathrm{HEPES}$ ). C, Regenerative neuritic growth velocity from $\mathrm{NKCC}^{-/-}$is significantly faster compared with NKCC $1^{+/+}$mice. $\boldsymbol{D}$, Silencing NKCC1 expression with an intrathecal injection of NKCC1 siRNA once a day for $5 \mathrm{~d}$ significantly decreased growth velocity of rhodamine-labeled regenerating neurons. No modification of growth velocity was seen with control siRNA compared with nontreated axotomized neurons. ${ }^{* *} p<0.01,{ }^{* * *} p<0.001$, one way ANOVA.

neurons (Galan and Cervero, 2005). From studies in nonneuronal cells, an influx of ions through NKCC1 is regulated by phosphorylation, causing a stimulation of NKCC1 activity (Darman and Forbush, 2002; Flatman, 2002). Although we could not directly demonstrate in vitro that such phosphorylation of NKCC1 is responsible for intracellular $\mathrm{Cl}^{-}$accumulation, we have shown that changes in phosphorylation, through either phosphatase inhibition or kinase inhibition, do result in $\left[\mathrm{Cl}^{-}\right]_{\mathrm{i}}$ variations in vitro, consistent with activation or inactivation of NKCC1 activity. Our results are in agreement with previous reports showing that, in addition to transcriptional modifications, peripheral nerve injury induces early and long-term modifications in the phosphorylation state of various proteins. Among the most analyzed, the transcription factor STAT3 (signal transducer and activator of transcription 3), activated by the cytokine pathway, is phosphorylated. Interestingly, the phosphorylated STAT3 is associated with regenerative growth not only in vivo (Qiu et al., 2005 ) but also in vitro (Liu and Snider, 2001), confirming the long-term maintenance of some forms of phosphorylation. Heat shock protein 27 phosphorylation is also required for injured sensory neuron survival (Benn et al., 2002). Although the signaling pathways involved in NKCC1 phosphorylation after nerve injury remain to be determined, we have shown for the first time that a potential role of an increased activity of NKCC1 through phosphorylation is related to the regenerative growth of sensory neurons.
The increase in $\left[\mathrm{Cl}^{-}\right]_{\mathrm{i}}$ reported in the present study could induce various cellular processes, ultimately leading to an accelerated neuritic growth. Activation of NKCC1 leads to cellular uptake of $\mathrm{NaCl}$ and $\mathrm{KCl}$ and thus to cell swelling. The extension of the plasma membrane and the addition of new elements to the actin filaments accompanying neuritic growth are thought to be facilitated by protrusion of the cell membrane, which may be caused by local osmotic swelling. The membrane tension hypothesis proposes that high tensions favor the recruitment of membrane to the surface, whereas low tensions favor retrieval (Dai et al., 1998). Increase in $\left[\mathrm{Cl}^{-}\right]_{\mathrm{i}}$ is often correlated to an increase in osmotic tension (Chavas et al., 2004). According to the osmotic hypothesis, the tension associated with a volume increase could be a mechanism by which a cell regulates its growth.

Besides the membrane tension hypothesis that favors interactions between physical forces and membrane building, cell swelling is often associated with an increase in intracellular calcium concentration in many cell types, including sensory neurons (Okada et al., 2001; Viana et al., 2001; Alessandri-Haber et al., 2003). Calcium is a well known second messenger, and increase in its intracellular concentration regulates numerous kinases involved in growth (Henley and Poo, 2004). The best example for such positive crosstalk between chloride and calcium homeostasis in neurons is the excitatory action of the neurotransmitter GABA that occurs during the development of the CNS. The depolarizing effects of $\mathrm{GABA}$, via the $\mathrm{GABA}_{\mathrm{A}}$ receptor, are attributed to an intracellular accumulation of $\mathrm{Cl}^{-}$in immature neurons attributable to a low level of expression of KCC2 (Ben-Ari, 2002; Stein and Nicoll, 2003). GABA receptor-induced depolarization produces an increased concentration of intracellular calcium that could be the molecular basis for the trophic actions of GABA on neuronal development (Represa and Ben-Ari, 2005). Although it has been shown that growth of immature sensory neurons is activity dependent (Fields, 1998; Gomez and Spitzer, 1999; Gomez and Zheng, 2006), no data are available concerning the role of relationships between $\left[\mathrm{Cl}^{-}\right]_{\mathrm{i}}$ and intracellular calcium transients on the regenerative growth of adult sensory neurons. Although it is tempting to speculate that molecular mechanisms involved in embryonic growth could be similar in adult regenerative growth, such experimental evidence is still lacking (Snider et al., 2002).

In conclusion, although much evidence indicates that changes in intracellular chloride profoundly affect cell excitability and contribute to painful behaviors after injury, our study emphasizes the importance of chloride homeostasis in the process of regenerative growth of sensory neurons. Future studies will be aimed at identifying whether NKCC1 affects regenerative growth via changes in osmotic tension or via secondary intracellular calcium effects.

\section{References}

Alessandri-Haber N, Yeh JJ, Boyd AE, Parada CA, Chen X, Reichling DB, Levine JD (2003) Hypotonicity induces TRPV4-mediated nociception in rat. Neuron 39:497-511.

Alvarez-Leefmans FJ, Leon-Olea M, Mendoza-Sotelo J, Alvarez FJ, Anton B, Garduno $\mathrm{R}$ (2001) Immunolocalization of the $\mathrm{Na}^{+}-\mathrm{K}^{+}-2 \mathrm{Cl}^{-}$cotransporter in peripheral nervous tissue of vertebrates. Neuroscience 104:569-582.

Andre S, Boukhaddaoui H, Campo B, Al-Jumaily M, Mayeux V, Greuet D, Valmier J, Scamps F (2003) Axotomy-induced expression of calciumactivated chloride current in subpopulations of mouse dorsal root ganglion neurons. J Neurophysiol 90:3764-3773.

Araki T, Nagarajan R, Milbrandt J (2001) Identification of genes induced in peripheral nerve after injury. Expression profiling and novel gene discovery. J Biol Chem 276:34131-34141. 
Ben-Ari Y (2002) Excitatory actions of gaba during development: the nature of the nurture. Nat Rev Neurosci 3:728-739.

Benn SC, Perrelet D, Kato AC, Scholz J, Decosterd I, Mannion RJ, Bakowska JC, Woolf CJ (2002) Hsp27 upregulation and phosphorylation is required for injured sensory and motor neuron survival. Neuron 36:45-56.

Cafferty WB, Gardiner NJ, Gavazzi I, Powell J, McMahon SB, Heath JK, Munson J, Cohen J, Thompson SW (2001) Leukemia inhibitory factor determines the growth status of injured adult sensory neurons. J Neurosci 21:7161-7170.

Chavas J, Forero ME, Collin T, Llano I, Marty A (2004) Osmotic tension as a possible link between $\mathrm{GABA}(\mathrm{A})$ receptor activation and intracellular calcium elevation. Neuron 44:701-713.

Coull JA, Boudreau D, Bachand K, Prescott SA, Nault F, Sik A, De Koninck P, De Koninck Y (2003) Trans-synaptic shift in anion gradient in spinal lamina I neurons as a mechanism of neuropathic pain. Nature 424:938-942.

Dai J, Sheetz MP, Wan X, Morris CE (1998) Membrane tension in swelling and shrinking molluscan neurons. J Neurosci 18:6681-6692.

Darman RB, Forbush B (2002) A regulatory locus of phosphorylation in the $\mathrm{N}$ terminus of the $\mathrm{Na}-\mathrm{K}-\mathrm{Cl}$ cotransporter, NKCC1. J Biol Chem 277:37542-37550.

Delpire E, Lu J, England R, Dull C, Thorne T (1999) Deafness and imbalance associated with inactivation of the secretory $\mathrm{Na}-\mathrm{K}-2 \mathrm{Cl}$ co-transporter. Nat Genet 22:192-195.

Fields RD (1998) Effects of ion channel activity on development of dorsal root ganglion neurons. J Neurobiol 37:158-170.

Flatman PW (2002) Regulation of Na-K-2Cl cotransport by phosphorylation and protein-protein interactions. Biochim Biophys Acta 1566:140-151.

Flemmer AW, Gimenez I, Dowd BF, Darman RB, Forbush B (2002) Activation of the Na-K-Cl otransporter NKCC1 detected with a phosphospecific antibody. J Biol Chem 277:37551-37558.

Galan A, Cervero F (2005) Painful stimuli induce in vivo phosphorylation and membrane mobilization of mouse spinal cord NKCC1 cotransporter. Neuroscience 133:245-252.

Gomez TM, Spitzer NC (1999) In vivo regulation of axon extension and pathfinding by growth-cone calcium transients. Nature 397:350-355.

Gomez TM, Zheng JQ (2006) The molecular basis for calcium-dependent axon pathfinding. Nat Rev Neurosci 7:115-125.

Henley J, Poo MM (2004) Guiding neuronal growth cones using $\mathrm{Ca}^{2+}$ signals. Trends Cell Biol 14:320-330.

Jacob JM, McQuarrie IG (1993) Acceleration of axonal outgrowth in rat sciatic nerve at one week after axotomy. J Neurobiol 24:356-367.

Jiang G, Klein JD, O'Neill WC (2001) Growth factors stimulate the Na-K$2 \mathrm{Cl}$ cotransporter $\mathrm{NKCC} 1$ through a novel $\mathrm{Cl}^{-}$-dependent mechanism. Am J Physiol Cell Physiol 281:C1948-C1953.

Kaila K, Voipio J (1987) Postsynaptic fall in intracellular pH induced by GABA-activated bicarbonate conductance. Nature 330:163-165.

Karadsheh MF, Byun N, Mount DB, Delpire E (2004) Localization of the $\mathrm{KCC} 4$ potassium-chloride cotransporter in the nervous system. Neuroscience 123:381-391.

Kyrozis A, Reichling DB (1995) Perforated-patch recording with gramicidin avoids artifactual changes in intracellular chloride concentration. J Neurosci Methods 57:27-35.

Laird JM, Garcia-Nicas E, Delpire EJ, Cervero F (2004) Presynaptic inhibition and spinal pain processing in mice: a possible role of the NKCC1 cation-chloride co-transporter in hyperalgesia. Neurosci Lett 361:200-203.

Lang F, Busch GL, Volkl H (1998) The diversity of volume regulatory mechanisms. Cell Physiol Biochem 8:1-45.

Lankford KL, Waxman SG, Kocsis JD (1998) Mechanisms of enhancement of neurite regeneration in vitro following a conditioning sciatic nerve lesion. J Comp Neurol 391:11-29.
Liu RY, Snider WD (2001) Different signaling pathways mediate regenerative versus developmental sensory axon growth. J Neurosci 21:RC164(1-5).

Lytle C (1997) Activation of the avian erythrocyte Na-K-Cl cotransport protein by cell shrinkage, cAMP, fluoride, and calyculin-A involves phosphorylation at common sites. J Biol Chem 272:15069-15077.

Makwana M, Raivich G (2005) Molecular mechanisms in successful peripheral regeneration. FEBS J 272:2628-2638.

Mechaly I, Bourane S, Piquemal D, Al-Jumaily M, Venteo S, Puech S, Scamps F, Valmier J, Carroll P (2006) Gene profiling during development and after a peripheral nerve traumatism reveals genes specifically induced by injury in dorsal root ganglia. Mol Cell Neurosci 32:217-229.

Nabekura J, Ueno T, Okabe A, Furuta A, Iwaki T, Shimizu-Okabe C, Fukuda A, Akaike N (2002) Reduction of KCC2 expression and $\mathrm{GABA}_{\mathrm{A}}$ receptor-mediated excitation after in vivo axonal injury. J Neurosci 22:4412-4417.

Okada Y, Maeno E, Shimizu T, Dezaki K, Wang J, Morishima S (2001) Receptor-mediated control of regulatory volume decrease (RVD) and apoptotic volume decrease (AVD). J Physiol (Lond) 532:3-16.

O’Neill WC (1999) Physiological significance of volume-regulatory transporters. Am J Physiol 276:C995-C1011.

Payne JA, Rivera C, Voipio J, Kaila K (2003) Cation-chloride cotransporters in neuronal communication, development and trauma. Trends Neurosci 26:199-206.

Plotkin MD, Kaplan MR, Peterson LN, Gullans SR, Hebert SC, Delpire E (1997) Expression of the $\mathrm{Na}^{+}-\mathrm{K}^{+}-2 \mathrm{Cl}^{-}$cotransporter BSC2 in the nervous system. Am J Physiol 272:C173-C183.

Qiu J, Cafferty WB, McMahon SB, Thompson SW (2005) Conditioning injury-induced spinal axon regeneration requires signal transducer and activator of transcription 3 activation. J Neurosci 25:1645-1653.

Represa A, Ben-Ari Y (2005) Trophic actions of GABA on neuronal development. Trends Neurosci 28:278-283.

Seijffers R, Allchorne AJ, Woolf CJ (2006) The transcription factor ATF-3 promotes neurite outgrowth. Mol Cell Neurosci 32:143-154.

Smith DS, Skene JH (1997) A transcription-dependent switch controls competence of adult neurons for distinct modes of axon growth. J Neurosci 17:646-658.

Snider WD, Zhou FQ, Zhong J, Markus A (2002) Signaling the pathway to regeneration. Neuron 35:13-16.

Stein V, Nicoll RA (2003) GABA generates excitement. Neuron 37:375-378.

Sung KW, Kirby M, McDonald MP, Lovinger DM, Delpire E (2000) Abnormal $\mathrm{GABA}_{\mathrm{A}}$ receptor-mediated currents in dorsal root ganglion neurons isolated from $\mathrm{Na}-\mathrm{K}-2 \mathrm{Cl}$ cotransporter null mice. J Neurosci 20:7531-7538.

Tan PH, Yang LC, Shih HC, Lan KC, Cheng JT (2005) Gene knockdown with intrathecal siRNA of NMDA receptor NR2B subunit reduces formalin-induced nociception in the rat. Gene Ther 12:59-66.

Tanaka K, Zhang QL, Webster HD (1992) Myelinated fiber regeneration after sciatic nerve crush: morphometric observations in young adult and aging mice and the effects of macrophage suppression and conditioning lesions. Exp Neurol 118:53-61.

Viana F, de la Pena E, Pecson B, Schmidt RF, Belmonte C (2001) Swellingactivated calcium signalling in cultured mouse primary sensory neurons. Eur J Neurosci 13:722-734.

Waldegger S, Steuer S, Risler T, Heidland A, Capasso G, Massry S, Lang F (1998) Mechanisms and clinical significance of cell volume regulation. Nephrol Dial Transplant 13:867-874.

Xiao HS, Huang QH, Zhang FX, Bao L, Lu YJ, Guo C, Yang L, Huang WJ, Fu G, Xu SH, Cheng XP, Yan Q, Zhu ZD, Zhang X, Chen Z, Han ZG (2002) Identification of gene expression profile of dorsal root ganglion in the rat peripheral axotomy model of neuropathic pain. Proc Natl Acad Sci USA 99:8360-8365. 